\title{
Competitive Position of Enterprises, Corporate Growth and Audit Fees: Based on Empirical Evidence from Chinese A-Share Listed Companies
}

\author{
Sifan Wang \\ School of Management, Jinan University, Guangzhou, China \\ Email: windbrand@vip.qq.com
}

How to cite this paper: Wang, S. F. (2020). Competitive Position of Enterprises, Corporate Growth and Audit Fees: Based on Empirical Evidence from Chinese A-Share Listed Companies. Modern Economy, 11, 453-474.

https://doi.org/10.4236/me.2020.112034

Received: January 16, 2020

Accepted: February 18, 2020

Published: February 21, 2020

Copyright $\odot 2020$ by author(s) and Scientific Research Publishing Inc. This work is licensed under the Creative Commons Attribution International License (CC BY 4.0).

http://creativecommons.org/licenses/by/4.0/

\begin{abstract}
The competitive position of an enterprise usually changes dynamically with the continuous growth and development of the enterprise. In this process, the business risks of the enterprise also change. According to the audit demand insurance theory, companies often use auditing to avoid and reduce risks, and auditors usually consider the corresponding risk premium in order to protect their own interests. This article uses the non-financial companies in China's A-share market from 2011 to 2016 as a sample to study the impact of enterprises' competitive position and growth on its audit fees. The research results show that: the competitive position of the company has a negative impact on audit fees; the growth of the company has a positive impact on audit fees; Further research shows that the impact of enterprises' competitive position on audit fees is no longer significant in high-growth companies and still significant in low-growth companies, so corporate growth has a weakening effect on this relationship. This research enriches the content of the research on influencing factors of audit fees, and also has certain significance for the audit fees of accounting firms in practice.
\end{abstract}

\section{Keywords}

Competitive Position of Enterprises, Corporate Growth, Audit Fees

\section{Introduction}

With the continuous development of modern economy and society, the scale of Chinese companies has continued to grow. While expanding in scale, these listed companies are also facing severe market environment and fierce market compe- 
tition. In this economic environment, some companies have reached the position of market leader due to their strong competitiveness, occupying a large market share in the entire industry, while others are only at the bottom because of their smaller market share. However, the competitive position of enterprises is not always the same. In the fierce market competition, enterprises will always face challenges from many aspects. Therefore, those companies with high competitive status may also have lower growth because they cannot break through their own development bottlenecks, and those innovative companies may also have higher growth due to the development of key technologies and gradually improve their competitive position.

In general, audit fees are affected by two main factors: audit cost and audit risk. According to the audit demand insurance theory, business owners try to use the audit mechanism to allow auditors to share certain corporate risks, and auditors are equivalent to collecting audit fees in the form of "insurance". Therefore, auditors usually consider the risks of the enterprise when deciding the audit pricing. Both the competitive position and the growth of the company may affect the judgment of the certified public accountant on the audit risk of the enterprise, which may lead to changes in audit fees. However, the existing literature on audit fees has insufficient research on the impact of this aspect. Although there have been studies on the impact of enterprises' competitive position on audit fees, it has not taken into account the impact of corporate growth; some of the existing literature has some conflicting conclusions. So the impact of the competitive position and growth of enterprises on audit fees is worthy of in-depth study. At the same time, by studying the impact of the company's competitive position and growth on audit fees, it has certain significance for the audit fee regulation of audit firms in the audit market.

This article is different from previous research. The main innovation is that according to the theory of auditing insurance and principal-agent theory, it studies the impact on audit fees from two aspects of enterprises' competitive position and corporate growth. The research on the impact of product market competition intensity on audit fees in the industry has ignored the important factor of the impact of the company's own competition intensity on audit fees. At the same time, this article studies the impact of corporate growth on audit fees. According to the audit demand insurance theory, the audit fee charged by the auditor to the enterprise is equivalent to the insurance premium. Therefore, high-growth and profit-making companies, because of their higher risks, have relatively high audit fees; those with low-growth and income have the opposite. Previous researchers have not studied the relationship between corporate growth and audit fees from this perspective.

Finally, the article examines the role of corporate growth in regulating the relationship between competitive position of enterprises and audit fees. This has not been considered in previous studies. The growth differences between different companies will directly affect the competitiveness of the entire industry's product market and the selection of individual companies' own competitive 
strategies, so that the growth of the company will have a weakening effect on the competitive position; at the same time, in the context of the rapid economic growth of the entire country, it is often accompanied by fierce or even excessive competition among industry and enterprises, this fierce competition will weaken the company's own competitive position and bring more uncertainty to the company's future operations, which will affect the judgment of auditors in audit pricing; for some more innovative industry companies, because of their emerging technology products, business philosophy and more excellent opportunities for corporate growth, which will bring strong competitive pressure to the entire market, and will directly stimulate companies at the end to carry out technological innovation and concept innovation, which will also increase market competition and weaken the impact of enterprises' competitive position on audit fees. Therefore, by considering the relationship between the competitive position of enterprises and audit fees under different growth groups, this article explains the impact of the competitive position of enterprises on audit fees in more depth, which has certain value and significance.

\section{Literature Review}

At present, there are still few related studies on the impact of enterprises' competitive position and growth on audit fees in China. This section intends to systematically sort out and summarize the relevant literature in an attempt to explain the core of enterprises' competitive position and growth. The relationship provides literature support for theoretical analysis and empirical testing of its internal mechanism and implementation path.

\subsection{About Audit Fees}

Research on audit fees has gone through a long time, so a very sound model has been basically established. The factors that affect audit fees are mainly divided into three aspects: corporate factors, firm and auditor factors, and external environmental factors. This section summarizes the main influencing factors of audit fees through literature review, and provides literature support for subsequent research.

\subsubsection{Corporate Factors}

The size of an enterprise directly affects the audit time and audit effort that a certified public accountant spends, thus affecting the final audit fees. Zhang and Huang (2014) research found that the size of assets audited by the firm is a key factor in audit fees, and the size of corporate assets has a significant positive impact on audit fees. If the auditee's business is more complex, the auditor's audit pricing will be increased. Vafeas and Waegelein (2007) found that the number of foreign branch operations of the audited company is significantly positively related to audit pricing. Li et al. (2014) used the data of listed companies from 2007 to 2011 as a sample. The study found that when there are major deficiencies in the company's internal control, the audit fees paid by the company also 
increase. He and Liu (2015) took the manager's ability as the research object, analyzed the ways in which managers influence audit fees, and found that the manager's ability of the audited institution had a negative impact on audit fees. Leventis \& Dimitropoulos (2010) research found that there is a significant positive correlation between the degree of earnings management of smaller listed companies and audit fees; while earnings management has little effect on the audit fees of large-scale listed companies. $\mathrm{Zhu}, \mathrm{Wu}$, and Tian (2017) research found that in the absence of separation of rights between listed companies, when the shareholding ratio of major shareholders is low, the shareholding ratio of major shareholders is negatively related to audit fees; the shareholder's shareholding ratio is positively related to audit fees.

\subsubsection{Firm and Auditor Factors}

Zhang and Tian (2016) examined from a local level whether an accounting firm with industry expertise can obtain audit fee premiums based on differentiated audit services, and whether the industry knowledge it possesses will be transferred in homogeneous industries to achieve economies of scale and reduce audit fees. It was found that local-level industry expertise firms charge higher audit fees than firms that do not have this feature. Choi et al. (2008) pointed out that due to the difference in audit quality, the audit fee premium of large accounting firms (such as the International Big Four) is widespread around the world, and it can reach a maximum of $53.7 \%$. This shows that the larger the firm, the higher the audit cost. Li, Wang and Yang (2012) studied the impact of the individual characteristics of the auditing provider-the signing CPA on the audit expense rate, and set five variables: gender, age, education, profession, and practice time. Research shows that the age, profession, and practice time of auditors are significantly related to the audit expense rate.

\subsubsection{External Environmental Factors}

Liu et al. (2014) believed that the more negative media reports the company faces, the higher the audit fees. Further analysis found that the negative media reports on accounting and the first negative media reports will cause auditors to raise audit fees. Ariningrum and Diyanty (2017) used a sample of non-financial companies listed on the Indonesian Stock Exchange during the period 2012-2015. The study found that political connections can have a positive impact on audit fees, as political connections within the company can increase the company's audit risk. The effectiveness of the board of directors and the audit committee can have a positive impact on audit fees. This is because the company's board of directors and audit committees often want auditors to improve the quality of audits, and are therefore willing to pay more audit fees to improve audit quality. Liu, Li, and Sun (2017) examined the impact of media negative reports on listed companies on audit pricing and audit delays, and found that media negative reports have a significant positive relationship with audit pricing, but have no significant relationship with audit delays that reflect audit efforts. This shows that for customers with more negative reports, auditors will charge a 
risk premium to transfer their risks, instead of reducing risks by increasing audit investment.

As mentioned above, the impact of the company's competitive position and growth on audit fees is mainly from the perspective of the company itself. The specific reasons are described in the following analysis.

\subsection{About Audit Fees and Risks}

As Chinese scholars currently have less research on audit fees in terms of product market competition, competitive position and growth of enterprises, however, the impact of enterprises' competitive position and growth on audit fees mainly occurs through the audit risk factor, this section first reviews audit fees and corporate risks based on audit demand insurance theory.

Wang et al. (2014) found that the higher the efficiency of corporate operations and corporate governance, the lower the legal risk of the enterprise, and the smaller the size of the accounting firm, the stronger the signal role of large clients and the stronger the effect of reducing audit fees. Xu and Wang (2012) examined how internal control affects the auditor's behavior from the perspective of audit fees and audit opinions. It found that companies with poor internal controls exposed auditors to greater audit risks, which led to auditors' demands for increased risk premiums, which in turn increased audit fees. Zhang and Huang (2013) examined the relationship between corporate risk and audit fees based on the exogenous impact of the 2008 financial crisis, and found that when the company's operating risk increased during the crisis, audit fees from accounting firms increased. Zhai et al. (2017) believe that for companies with pledge of controlling shareholder equity, auditors will increase audit investment, charge more audit fees, and issue more non-standard unqualified audit opinions. This further illustrates that the higher the risk facing the company, the higher the audit fee charged by the auditor. Yang et al. (2017) introduced an innovative method of text mining that uses unstructured text disclosure in annual reports to assess corporate risk. The study found that audit fees are significantly positively related to the company's specific financial, strategic, and operational risks. Cullen et al. (2018) believe that when banks choose the Big Four as auditors, there is a significant positive correlation between the bank's asset securitization risk (ASR) and audit fees, but non-Big four audit fees do not. Before the global financial crisis, audit fees had a positive correlation with ASR, especially for those companies that lost money that year. This also shows that there is a positive correlation between audit fees and risks.

According to the above literature, it can be found that there is a significant positive correlation between corporate risk and audit fees. Auditors usually adjust audit fees based on the risks of the enterprise to obtain part of the risk premium.

\subsection{About Competitive Position of Enterprises and Audit Fees}

As for the relationship between the competitive position of enterprises and audit 
fees, China and foreign scholars still have few researches, mainly focusing on product market competition and audit fees, which are mainly from the strength of the company's own product market competition and the products of the industry in which the company is located. There are two aspects of the degree of market competition. The current research mostly focuses on the impact of the degree of product market competition in the industry in which the company is located on the audit fees. There is a correlation between the competitive position of the company and the strength of its own product market competition. Generally speaking, the stronger the product market competitiveness of the company, the higher the competitive position of the company, and the weaker the product market competitiveness, the lower the competitive position of the company.

Irvine and Pontiff (2009) researched the volatility of stock-specific returns, cash flow, and product market competition, and found that those companies with higher market competitive positions have greater ability to withstand external shocks and risks. Positively, those companies with higher competitive positions are better able to use various methods to avoid risks. Therefore, for such companies, auditors usually only charge less risk premiums and lower audit fees. Wang \& Chui (2010) used US listed companies as a sample, and empirically found that as the degree of competition in the product market became more intense, the competitive position of enterprises was lower, and audit fees also increased. This is because the stronger the degree of market competition, the greater the company's operating risk. Based on the audit demand insurance theory, the auditor's audit pricing is higher. Xing and Chen (2013) research found that the product market competition intensity has a significant negative impact on audit fees, and the competitive position of listed companies has a significant negative impact on audit fees. Therefore, the relationship between enterprises' competitive position and audit fees is mainly caused by operating risk. $\mathrm{Wu}$, Yang and Wei (2012) research found that the significant increase in idiosyncratic risk is significantly positively related to the intensified competition in the product market of China's listed companies; but in a relatively concentrated industry structure and significant market power, it can effectively weaken the company's stock idiosyncratic risk and stabilize the company Returns, to a certain extent, indicate that the stronger the market power of an enterprise (that is, the higher its competitive position), the smaller the risks it faces, thereby reducing audit fees. Huang, Jennings, and Yu (2017) used the double difference method to study the impact of product market competition intensity on corporate earnings forecast disclosure. It examines the intensity of competition in the product market by significantly reducing the US import tariff rate, thereby determining the competitive exogenous growth of Chinese companies in the US product market. The results show that tariff cuts are associated with a significant decline in disclosures of annual earnings forecasts for domestic companies in the United States. This also shows that those companies that are less competitive are more reluctant to disclose their earnings forecasts, which increases the auditor's audit risk. Liu and Luo (2018) research found that customer relationship in- 
vestment and audit pricing are significantly negatively correlated. After introducing product market competition factors, this negative correlation is more significant among companies with weaker product market competition, so they compete in the product market. In weaker industries, companies face lower external risks, and auditors usually charge lower audit fees.

Some scholars have made different research conclusions about the relationship between them. Chen and $\mathrm{Xu}$ (2011) empirically analyzed whether the degree of market competition between the Shenzhen and Shanghai A-share listed companies in 2000-2009 has a governance effect on earnings management behavior. The study found that with the increase of the company's product market competition, the company's earnings management behavior became more obvious, and forced listed companies to conduct positive earnings management, which further intensified the agency problems between shareholders and management. The above situation increases the audit risks faced by the auditors, and the auditors obtain risk compensation by increasing the audit fees. Hang and Shin (2018) analyzed the relationship between corporate market power and audit fees. Specifically, it determines the impact of market forces on audit fees as measured by market share, and the impact of corporate governance structure on the relationship between market forces and audit fees. It turns out that the company's market power is positively related to audit fees, and this result is obvious for companies with good corporate governance.

To sum up, this article believes that the higher the competitive position of an enterprise, the lower the business risks it faces. Therefore, according to the audit demand insurance theory, the competitive position of an enterprise has a negative impact on audit fees.

\subsection{About Business Growth and Audit Fees}

For the relationship between corporate growth and audit fees, scholars at home and abroad are still few. However, many scholars have studied the relationship between accounting stability and corporate growth from the perspective of accounting soundness. Accounting soundness can be used as a restrictive mechanism to reduce auditors' risk level and audit fees. This section summarizes the relationship between corporate growth and risk, and the relationship between corporate growth and audit fees. According to the theory of audit demand insurance, from the perspective of risk, the higher the growth of a company, the higher the risks it faces, and the higher the audit risks faced by the auditors, and the higher the audit fees charged.

Lin et al. (2011) studied the influence of CEO control and corporate growth on audit pricing. The results found that $\mathrm{CEO}$ control and corporate growth have significant positive impacts on audit pricing, but most Chinese listed companies are in the early stages of growth. The impact of CEO control on audit pricing does not depend on growth factors. This is to a certain extent It shows that the growth of enterprises has a positive impact on audit pricing. Xiang and Yang (2013) research found that the higher-growth companies, the more inclined to 
pay higher audit fees, and the higher-growth companies tend to choose the "Big Four" to provide audit services for them. Li (2015) believes that auditors issue different types of assurance opinions on companies with different growth capabilities in different industries; prudent work and the cost of additional labor have prompted higher levels of pricing for higher-growth companies, showing a clear risk premium level. Bushman, Hendricks and Williams (2016) investigated whether the intensity of competition would increase or decrease the risk of the banking system. It uses text-based competition metrics and leverages instrumental variable analysis of exogenous variation in bank deregulation. The research results show that the higher the competition intensity will increase the risk of the banking system, so the corresponding audit risk will also increase accordingly.

In addition, some scholars have put forward the opposite argument about the relationship between corporate growth and audit fees. Liu and Min (2018) used China's A-share manufacturing listed companies from 2007 to 2016 as research samples to study the relationship between internal control quality, corporate growth, and credit risk, respectively. Research shows that the quality of internal control and the growth of the company are negatively related to credit risk. When the quality of internal control of the company is low, high growth has little effect on reducing credit risk; when the growth of the company is low, high internal control quality does not significantly reduce corporate credit risk. Therefore, this study reflects from the side that the higher the growth of the company, the less risk it faces. According to the theory of audit demand insurance, the audit fee required by the auditor is correspondingly lower. Cao and Chang (2015) research results using construction enterprises as a sample show that the bank's financial credit evaluation of enterprises is positively related to the growth of enterprises. When banks make credit decisions, they generally believe that high-growth companies have great potential for future development, many investment opportunities, relatively high levels of profitability, and higher ability to repay loans. From the perspective of the bank's credit policy, the lower the credit risk faced by those high-growth companies, the lower the audit fees should be. Wei, Huang and Zhang (2017) examined the relationship between managers' risk appetite and the transparency of accounting information under the regulation of corporate growth. In the full sample empirical evidence, it confirms the assumption that the higher the growth of the company and the greater the transparency of accounting information disclosure, the higher the transparency of the accounting information disclosure, therefore, the side shows that the higher the company's growth, the lower the audit fees.

To sum up, this article believes that for high-growth companies, they tend to face greater capital market pressures, as well as greater cash flow shortage risks and operating risks; at the same time, high growth is usually accompanied by high returns, and benefits and risks are positively related. Then high-growth 
companies will inevitably have high risks, and auditors will require higher audit fees for such companies. The growth of enterprises has a significant positive impact on audit fees.

\subsection{The Impact of Corporate Growth on the Relationship between Enterprises' Competitive Position and Audit Fees}

Wu, Tan and Yang (2015) used the data from 2000 to 2012 of Shanghai and Shenzhen A-share listed companies as a sample to study the relationship between product market competition, growth, and stock-specific fluctuations, and test association of "competition-risk" ("PMC-risk"). The study found that the growth difference is a key environmental variable that affects the "PMC-risk" effect. The high growth pressures commonly faced by Chinese listed companies in the context of an emerging/transition economy are intensifying competition in their products and causing significant fluctuations in stock returns. An important promoter, high growth pressure has "intensifying competition effect".

Bartram et al. (2012) believe that the policy tilt enjoyed by high-growth companies will, on the one hand, induce competitors with similar strengths or technologies to intensify the "pet-style" competition for policy convenience. In addition, it is to actively respond to the potential threats of other stronger competitors; on the other hand, the market competition pressure brought by high-growth companies with new technologies or products and more growth potential will also directly stimulate the companies that are still downstream in the industry to improve their products or technology innovation, so as to obtain more development opportunities, which will directly or indirectly intensify competition among enterprises.

Alimov (2014) research found that trade liberalization can promote the rapid growth of enterprises and reduce the barriers to entry of the industry, thereby increasing the risk of companies' plundering investment opportunities. Therefore, companies must take relevant measures to deal with the threat of competition from new competitors. This shows from a side that in the case of high growth of the industry or enterprise, the potential competition risk will be greater, which will weaken the impact of the competitive position of the company on audit fees to a certain extent.

This article believes that the growth of enterprises will change the competition situation of the entire industry in some way and affect the competitive position of enterprises. Therefore, the growth of enterprises has a weakening effect on the relationship between the competitiveness of enterprises (the intensity of competition in the product market) and audit fees.

\section{Theoretical Analysis and Research Assumptions}

There are two main research paths on the impact of enterprises' competitive position on audit fees (Xing \& Chen, 2013): 1) The higher competitive position of the company means that the company's operating risk is lower, which makes the audit risk lower; 2) The higher the competitive position of an enterprise, the 
more serious the agency problems of internal owners and operators of the enterprise. The owner hopes to pass the agency cost to the auditor through auditing, which makes the auditor need more audit fees to transfer your own risk. According to the literature review in the previous section, this paper believes that the impact of enterprises' competitive position on audit fees is mainly the first path, so it is concluded that $\mathrm{H} 1$ : the competitive position of enterprises has a significant negative impact on audit fees.

Regarding the impact of the company's competitive position on audit fees, according to the audit demand insurance theory, from a risk perspective, the higher the growth of the company, the higher the risk it faces, and the higher the audit risk the auditor faces. The audit cost is higher, combined with the previous literature review, it is proposed that $\mathrm{H} 2$ : the growth of the company has a significant positive impact on audit fees.

Finally, according to the policy tilt enjoyed by the high-growth companies mentioned above, on the one hand, it will induce competitors with similar strength or technology to intensify the "pet-style" competition in order to obtain policy convenience. By joining such competition, in addition to seeking opportunities to strengthen themselves, it is also in order to actively respond to the potential threats of other stronger competitors; on the other hand, the market competition pressure brought by high-growth companies with new technologies or new products and more growth potential will also directly stimulate the downstream industries. The improvement of products or technological innovation by companies in order to obtain more development opportunities will directly or indirectly increase competition between enterprises. Therefore, the growth of enterprises will change the competitive situation of the industry to a certain extent and affect the competitive position of enterprises. This leads to hypothesis H3: The growth of the company has a weakening effect on the relationship between the company's competitive position and audit fees.

The hypothetical derivation process is shown in Figure 1. Based on the current research on audit costs, the article puts forward the above three assumptions from the perspective of audit risk through literature review and theoretical review.

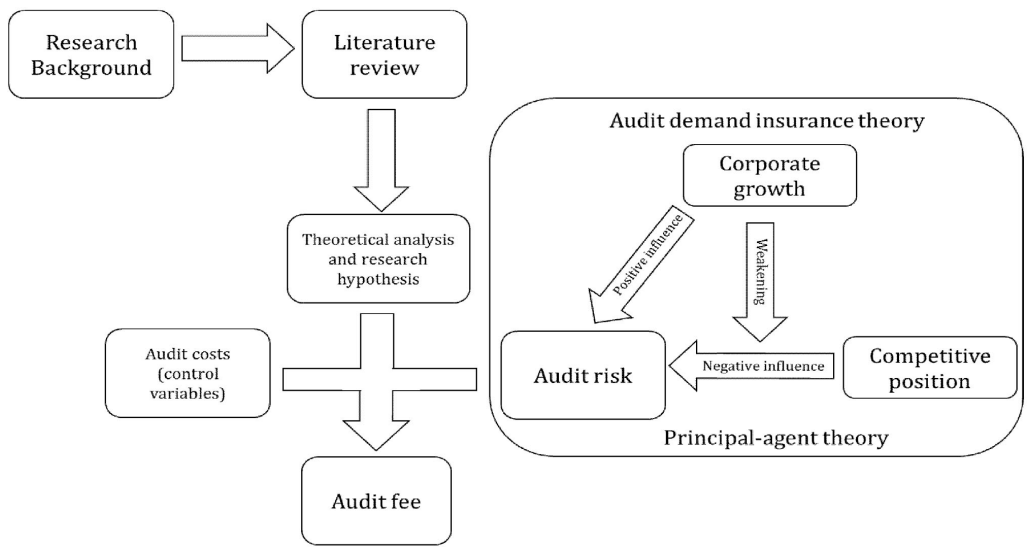

Figure 1. Derivation of research hypotheses. 


\section{Research Design}

Based on the theory of auditing demand insurance, principal-agent theory and research of scholars at home and abroad, and combined with China's current economic environment and institutional background, this paper selects the data of China's A-share listed companies from 2011 to 2016 from the CSMAR database and removes financial insurance industry, ST industry. The research focuses on the impact of enterprises' competitive position on audit fees, the impact of corporate growth on audit fees, and the impact of corporate growth on the relationship between competitive position and audit fees.

\subsection{Variable Selection}

Regarding audit fees (auditee), a common method is adopted, that is, the company's audit fees in that year take a natural logarithm.

Regarding the variable of competitive position of enterprises (PCM), the Lerner index is used to measure the competitive position of the market based on the methods of Xing \& Chen (2013) and Wu, Yang, \& Wei (2012). Lerner index is (operating income-operating costs-selling expenses-management expenses)/operating income. The larger the PCM value, the higher the company's competitive position in the industry and the stronger its pricing power.

Regarding the corporate growth variable (Grow), reference is made to the index selected by Ma \& Wang (2015), Wu, Han, \& Li (2016), and Lu, Jin, \& Chen (2006) when studying the growth of Chinese enterprises, that is, the main business revenue growth rate index [(Main business income for the current period-Main business income for the previous period)/Main business income for the previous period)].

According to previous studies, the following control variables were selected in this paper to reduce research errors.

The specific variable definitions are shown in Table 1.

\subsection{Model Building}

Firstly, based on Wang \& Chui (2010) and Xing \& Chen (2013)'s research framework on the impact of product market competition on audit fees, the Lerner Index is used to measure the competitive position of the company as an explanatory variable, and the control variables (including annual and industry) mentioned above are added, and audit fees is used as an explanatory variable to build model 1, model 1 is used to test $\mathrm{H} 1$ (the competitive position of a company has a significant negative impact on audit fees), as follows:

\footnotetext{
Auditfee $=\mathrm{PCM}+$ size + roa $+\mathrm{lev}+\mathrm{inv}+\mathrm{rec}+$ loss + big $4+$ register + ownership + change $+($ ind $1-$ ind 76$)+($ year $1-$ year 6$)$
}

Secondly, based on the audit demand insurance theory and the research of Lin et al. (2011) and Xiang \& Yang (2013), based on model 1, the growth rate of the main business is used to measure the growth of the enterprise as an explanatory variable, and the remaining variables remain unchanged to establish model 2, model 2 is used to test $\mathrm{H} 2$ (Corporate growth has a significant effect on audit fees 
Table 1. Variable definition table.

\begin{tabular}{|c|c|c|}
\hline Variable name & Symbol & Variable definitions \\
\hline audit fee & auditfee & $\begin{array}{l}\text { The natural logarithm of the company's } \\
\text { audit fees for the year }\end{array}$ \\
\hline competitive position & PCM & $\begin{array}{c}\text { (Operating income }- \text { operating costs }- \text { selling } \\
\text { expenses - administrative expenses)/operating income }\end{array}$ \\
\hline corporate growth & Grow & $\begin{array}{l}\text { (Main business income for the current period - Main } \\
\text { business income for the previous period)/ } \\
\text { Main business income for the previous period) }\end{array}$ \\
\hline enterprise size & size & Natural logarithm of total assets \\
\hline profitability & roa & Company net profit/total assets \\
\hline debt to asset ratio & lev & Total Liabilities/Total Assets \\
\hline \multirow{2}{*}{ business complexity } & inv & Inventory/total assets \\
\hline & rec & Accounts receivable/total assets \\
\hline whether to lose money & loss & The company's loss for the year is 1 , otherwise it is 0 \\
\hline nature of property right & ownership & $\begin{array}{l}\text { The company's ultimate controller } \\
\text { is } 1 \text { for the country, otherwise } 0\end{array}$ \\
\hline auditor change & change & Auditor changes take 1 , otherwise 0 \\
\hline accounting firm size & big4 & Big 4 take 1 , otherwise 0 \\
\hline regional impact & register & $\begin{array}{l}\text { Companies registered in Beijing, Shanghai, } \\
\text { Guangzhou and Shenzhen are 1, otherwise } 0\end{array}$ \\
\hline industry & ind & $\begin{array}{l}\text { Establish industry dummy variables according } \\
\text { to the industry classification of the SFC } 2012\end{array}$ \\
\hline year & year & Establish annual dummy variables by sample year \\
\hline
\end{tabular}

positive impact), as follows:

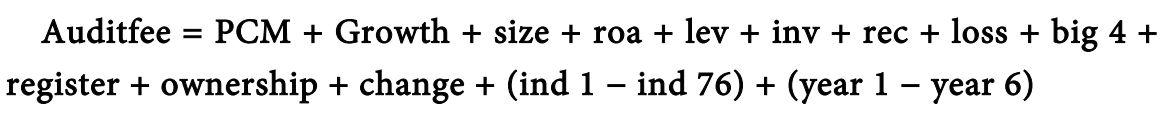

Finally, based on Wu, Tan, \& Yang (2015) research on enterprises' competitive position and growth relationship, this paper grouped the company's growth variables into high-growth and low-growth groups according to the average value, and performed group regression based on model one to test $\mathrm{H} 3$ (enterprise growth has a weakening effect on the relationship between the company's competitive position and audit fees).

\section{Empirical Analysis}

\subsection{Descriptive Statistics}

This section conducts a descriptive statistical analysis of the main variables in the model, including the audit fees (explained variables), enterprises' competitive position and growth (explanatory variables), enterprise size, profitability, financial leverage, complexity of the company's business, whether the company lost money in the year, the nature of the company's property rights (state-owned and non-state-owned enterprises), changes in auditors, the size of the account- 
ing firm, and the place of business registration (control variable). The specific results are shown in Table 2.

As can be seen from Table 2, the observed values of the samples are basically 11592 , and the number of observed values of each variable is not much different. The average audit fee is 13.50 , and the minimum value is 12.43 , and the maximum value is 15.54 . Since this variable is standardized by natural logarithm, this indicates that the audit fees of different companies vary widely, the same situation of the competitive position and growth of the company and the scale of the company. At the same time, the average value of the Lerner index for measuring the competitive position of an enterprise is 0.11 , and the value of the Lerner index is generally between 0 and 1 . The larger the value, the higher the competitive position. Therefore, the average value of 0.11 of the Lerner Index indicates that Chinese companies are in general in a low competitive position and the corresponding degree of corporate monopoly is also low. The average value of the company size variable is 22.00 , the maximum value is 25.54 , the minimum value is 19.57 , and the standard deviation is 1.24 , indicating that the size of China's listed companies varies greatly. The average value of corporate profitability variables is 0.04 , the maximum value is 0.19 , and the minimum value is -0.15 , which indicates that corporate profitability (return on assets) is generally at a general level, and even some companies still have negative profits due to losses. The average corporate financial leverage variable (asset-liability ratio) is 0.43 , the median is 0.42 , the maximum is 0.92 , and the minimum is 0.05 . This shows that debt management is very common in China, and most companies have an asset-liability ratio of more than $40 \%$. The business complexity variable is measured by using the proportion of inventory and accounts receivable in the total

Table 2. Descriptive statistics of main variables.

\begin{tabular}{ccccccc}
\hline $\begin{array}{c}\text { Variable } \\
\text { name }\end{array}$ & $\begin{array}{c}\text { Number } \\
\text { of samples }\end{array}$ & $\begin{array}{c}\text { Average } \\
\text { value }\end{array}$ & Median & $\begin{array}{c}\text { Standard } \\
\text { deviation }\end{array}$ & $\begin{array}{c}\text { Minimum } \\
\text { value }\end{array}$ & $\begin{array}{c}\text { Max } \\
\text { value }\end{array}$ \\
\hline auditfee & 11592 & 13.50 & 13.40 & 0.61 & 12.43 & 15.54 \\
PCM & 11592 & 0.11 & 0.09 & 0.14 & -0.45 & 0.52 \\
Grow & 10877 & 0.19 & 0.10 & 0.54 & -0.56 & 4.12 \\
size & 11592 & 22.00 & 21.85 & 1.24 & 19.57 & 25.54 \\
roa & 11592 & 0.04 & 0.04 & 0.05 & -0.15 & 0.19 \\
lev & 11592 & 0.43 & 0.42 & 0.22 & 0.05 & 0.92 \\
inv & 11566 & 0.16 & 0.12 & 0.15 & 0.00 & 0.76 \\
rec & 11582 & 0.11 & 0.09 & 0.10 & 0.00 & 0.46 \\
loss & 11592 & 0.09 & 0.00 & 0.28 & 0.00 & 1.00 \\
ownership & 11592 & 0.41 & 0.00 & 0.49 & 0.00 & 1.00 \\
change & 11592 & 0.66 & 1.00 & 0.47 & 0.00 & 1.00 \\
big4 & 11592 & 0.05 & 0.00 & 0.22 & 0.00 & 1.00 \\
register & 11592 & 0.27 & 0.00 & 0.45 & 0.00 & 1.00 \\
\hline
\end{tabular}


assets. The standard deviations of the two are 0.15 and 0.10 , which are relatively small in the descriptive statistics. The difference is relatively small among listed companies. Whether the average value of the company's loss variable is 0.09 , which means that $9 \%$ of the company's sample has a loss; The mean value of the property right variable is 0.41 , which means that $41 \%$ of the company samples are state-owned enterprises; The average value of the audit change variable is 0.66 , which indicates that audit changes are more common, and $66 \%$ of the samples have audit changes; The average value of the firm size variable is 0.05 , which means that only $5 \%$ of the sample companies audited by the four largest international accounting firms; The mean of company registration variables is 0.27 , which means that $27 \%$ of the sample companies are registered in first-tier cities.

\subsection{Multiple Regression Analysis and Endogenous Solution}

\subsubsection{Endogenous Solution}

The competitive status and corporate growth variables used in this paper are prone to internal problems due to too many influencing factors, which affects the robustness of the results. Therefore, before performing multivariate linear regression analysis, first use the instrumental variable method to deal with the endogeneity of the study, and avoid the problem of endogeneity by adding the appropriate instrumental variable (the logarithm of the number of executive shares) in the regression.

Generally speaking, an effective instrumental variable must meet the three requirements that are related to endogenous variables, not related to disturbance terms, and that instrumental variables must affect dependent variables through endogenous variables. The endogenous variables in this article are the variables of the competitive position of the enterprise. Therefore, two instrumental variables of the lagging phase of the competitive position of the enterprise and the number of senior management holdings are selected to solve the endogenous problem. The company's competitive position lags behind the first period to meet the requirements of instrumental variables, so it will not be repeated; the number of executives' holdings is essentially the company's equity incentives for executives. It can improve the company's operating performance in the favorable direction of the business owner, thereby enhancing the company's competitive position, and ultimately affect the audit fees charged by the auditor through the company's competitive position.

$\mathrm{Xu}$ and Feng (2016) empirically tested the relationship between executive equity incentives and audit pricing from the perspective of equity concentration. The increase in the shareholding of executives will significantly reduce audit pricing, and the negative relationship between executive equity incentives and audit pricing will be positively adjusted by the concentration of equity. Ni, Dai, and Zhang (2017) research found that in China, the audit fees of the experimental group companies that implement equity incentive plans are lower than those of the control group companies, and companies that implement equity incentive plans have lower audit fees after implementation than before implementation, 
the degree of audit fee reduction is directly proportional to the strength of equity incentives. Ma, Shen and Tian (2018) believe that audit fees increase with the increase in the level of executive compensation and incentives, indicating that higher levels of executive compensation and incentives mean higher audit fees; audit fees decrease as the level of executive equity incentives increases, this shows that listed companies can reduce auditing costs by increasing equity incentive levels.

In summary, according to the principal-agent theory and the auditing demand insurance theory, companies can reduce agency problems by increasing the level of equity incentives for executives, thereby motivating executives to work towards improving their competitive position, reducing the auditor's audit risk ultimately reduces audit fees. Based on this, it is reasonable to choose the number of senior management holdings as an instrumental variable.

The instrumental variable method is used to define the two variables of the lagging period of corporate competition and the number of shares held by senior management as instrumental variables. Both of these variables meet the requirements of instrumental variables that are related to the independent company's competitive position but not related to the perturbation term and affect audit fees through the company's competitive position. Both instrumental variables passed the over-identification test and the weak instrumental variable test, which shows that they meet the requirements of valid instrumental variables. The results are shown in Table 3.

According to the test results in Table 3, the number of executives' holdings and the competitive position of the company is lagging behind as an instrumental variable. The weak instrumental variable test has a Cragg-Donald statistic of 86.639 , which is greater than the critical value of 19.93 under $10 \%$ bias, that is

Table 3. Descriptive statistics and testing of instrumental variables.

\begin{tabular}{|c|c|c|}
\hline & (1) & (2) \\
\hline Instrument variable & $\begin{array}{c}\text { Number of } \\
\text { executive shares }\end{array}$ & $\begin{array}{l}\text { The lag period of } \\
\text { competitive position variables }\end{array}$ \\
\hline \multicolumn{3}{|l|}{$\begin{array}{l}\text { Descriptive statistics of } \\
\text { instrumental variables }\end{array}$} \\
\hline Average value & 14.606 & 0.110 \\
\hline Standard deviation & 3.407 & 0.138 \\
\hline \multicolumn{3}{|l|}{ Instrumental variable validity test } \\
\hline Sargan statistic (value) & 0.642 & 0.642 \\
\hline Cragg-Donald Wald F statistic & 86.639 & 86.639 \\
\hline Stock-Yogo bias critical value & $19.93(10 \%)$ & $19.93(10 \%)$ \\
\hline Underidentification test ( $\mathrm{p}$ value) & 0.000 & 0.000 \\
\hline \multicolumn{3}{|l|}{ Endogenous test } \\
\hline Davidson-MacKinnon test ( $\mathrm{p}$ value) & 0.167 & 0.167 \\
\hline
\end{tabular}


the assumption of rejecting weak instrument variables does not exist. Sargan statistic test with $\mathrm{p}$-value greater than 0.1 , that is, there is no over-identification problem; The p-value of the under-recognition test is less than 0.01 , so there is no problem of under-recognition. In summary, the selected instrument variable is a valid instrument variable. After adding instrumental variables, the Davidson-MacKinnon test with an endogenous test with a p-value greater than 0.1 indicates that accepting the null hypothesis that endogeneity has little effect on the estimation results, that is, there is no endogenous problem in the original model after adding instrumental variables.

\subsubsection{Endogenous Solution}

In order to test the research hypothesis, this paper uses the financial data of A-share listed companies in 2011-2016 to perform multiple linear regression analysis, and uses a fixed-effects model (fixed company and annual) to perform panel data regression. The explained variables are audit fees. The regression (1) in Table 4 uses model one to analyze hypothesis one; The regression (2) uses model two to test hypothesis two; Table 5 tests hypothesis three by using group growth regression as a regression with model one. The specific results are shown in the following two tables.

The regressions in (1), (2), and (3) in Table 4 are the three different regressions of the company's competitive position against audit fees, corporate growth versus audit fees, and corporate competitive status and growth versus audit fees before adding instrumental variables. Regression (4) and (5) are two different regressions on the company's competitive position and audit fees, and the company's competitive position and growth on audit fees. As can be seen from the above table, the regression coefficient of the competitive position of the company in the regression (1) is -0.188 and the $P$ value is 0.000 , which indicates that the competitive position of the company has a significant negative impact on audit fees at a significance level of $1 \%$, so $\mathrm{H} 1$ is established. The regression coefficient of the company's growth variable in regression (2) is 0.015 and the P value is 0.042 , which indicates that the company's growth has a significant positive impact on audit fees at a significance level of $5 \%$, so $\mathrm{H} 2$ is established. The above results are still significant after adding instrumental variables to solve the endogenous problem, indicating that the results are robust.

Table 5 shows the regression results of group regression for the entire sample using corporate growth variables. As shown in Table 5, before the instrumental variables were added, the regression coefficients of the competitive position of the companies were -0.024 and -0.020 , respectively, and the $\mathrm{P}$ values were 0.002 and 0.019 . A significant level of $5 \%$ has a significant negative impact on audit fees, which indicates that the impact of corporate growth on the relationship between enterprises' competitive position and audit fees did not weaken before adding instrumental variables. This result is most likely due to the impact of variable endogenous problems. After adding instrumental variables to solve the endogenous problem, in the high-growth group, the regression coefficient of the 
Table 4. Multiple regression analysis results 1 .

\begin{tabular}{|c|c|c|c|c|c|}
\hline & (1) & (2) & (3) & (4) & (5) \\
\hline $\begin{array}{l}\text { Instrument } \\
\text { variable }\end{array}$ & & & & \multicolumn{2}{|c|}{$\begin{array}{c}\text { Variables in executive } \\
\text { shareholding and corporate } \\
\text { competitive status lagged } \\
\text { by one period }\end{array}$} \\
\hline PCM & $\begin{array}{c}-0.188^{* * *} \\
(0.000)\end{array}$ & & $\begin{array}{c}-0.198^{* * *} \\
(0.000)\end{array}$ & $\begin{array}{c}-0.608^{* * *} \\
(0.009)\end{array}$ & $\begin{array}{c}-0.319^{*} \\
(0.093)\end{array}$ \\
\hline Grow & & $\begin{array}{l}0.015^{\star *} \\
(0.042)\end{array}$ & $\begin{array}{l}0.017^{* *} \\
(0.018)\end{array}$ & & $\begin{array}{c}0.028^{* * *} \\
(0.000)\end{array}$ \\
\hline size & $\begin{array}{c}0.339^{\star * *} \\
(0.000)\end{array}$ & $\begin{array}{c}0.323^{\star * *} \\
(0.000)\end{array}$ & $\begin{array}{c}0.331^{\star * *} \\
(0.000)\end{array}$ & $\begin{array}{c}0.368^{\star * \star} \\
(0.000)\end{array}$ & $\begin{array}{c}0.343^{* * *} \\
(0.000)\end{array}$ \\
\hline roa & $\begin{array}{c}0.493^{\star * *} \\
(0.000)\end{array}$ & $\begin{array}{l}0.251^{\star \star} \\
(0.014)\end{array}$ & $\begin{array}{c}0.452^{* * *} \\
(0.000)\end{array}$ & $\begin{array}{c}0.844^{\star * \star} \\
(0.009)\end{array}$ & $\begin{array}{c}0.383 \\
(0.149)\end{array}$ \\
\hline lev & $\begin{array}{c}0.120^{* * *} \\
(0.004)\end{array}$ & $\begin{array}{c}0.132^{* * *} \\
(0.002)\end{array}$ & $\begin{array}{c}0.120^{* * *} \\
(0.004)\end{array}$ & $\begin{array}{l}0.073^{\star *} \\
(0.050)\end{array}$ & $\begin{array}{c}0.052 \\
(0.160)\end{array}$ \\
\hline inv & $\begin{array}{c}0.086 \\
(0.184)\end{array}$ & $\begin{array}{c}0.105 \\
(0.115)\end{array}$ & $\begin{array}{l}0.108^{\star} \\
(0.096)\end{array}$ & $\begin{array}{l}0.118^{\star} \\
(0.057)\end{array}$ & $\begin{array}{l}0.144^{\star *} \\
(0.019)\end{array}$ \\
\hline rec & $\begin{array}{c}0.109 \\
(0.211)\end{array}$ & $\begin{array}{c}0.091 \\
(0.306)\end{array}$ & $\begin{array}{c}0.123 \\
(0.161)\end{array}$ & $\begin{array}{l}0.198^{\star *} \\
(0.025)\end{array}$ & $\begin{array}{c}0.129 \\
(0.128)\end{array}$ \\
\hline loss & $\begin{array}{l}0.025^{* *} \\
(0.017)\end{array}$ & $\begin{array}{c}0.031^{* * *} \\
(0.004)\end{array}$ & $\begin{array}{l}0.026^{* *} \\
(0.014)\end{array}$ & $\begin{array}{c}0.009 \\
(0.529)\end{array}$ & $\begin{array}{c}0.011 \\
(0.422)\end{array}$ \\
\hline ownership & $\begin{array}{l}-0.001 \\
(0.984)\end{array}$ & $\begin{array}{l}-0.008 \\
(0.870)\end{array}$ & $\begin{array}{l}-0.009 \\
(0.845)\end{array}$ & $\begin{array}{c}0.031 \\
(0.350)\end{array}$ & $\begin{array}{c}0.049 \\
(0.136)\end{array}$ \\
\hline change & $\begin{array}{l}-0.003 \\
(0.499)\end{array}$ & $\begin{array}{l}-0.005 \\
(0.225)\end{array}$ & $\begin{array}{l}-0.005 \\
(0.193)\end{array}$ & $\begin{array}{c}0.002 \\
(0.745)\end{array}$ & $\begin{array}{l}0.0002 \\
(0.972)\end{array}$ \\
\hline big4 & $\begin{array}{c}0.177^{\star * *} \\
(0.001)\end{array}$ & $\begin{array}{c}0.173^{\star * *} \\
(0.003)\end{array}$ & $\begin{array}{c}0.169^{\star * *} \\
(0.003)\end{array}$ & $\begin{array}{c}0.215^{\star * *} \\
(0.000)\end{array}$ & $\begin{array}{c}0.215^{\star * *} \\
(0.000)\end{array}$ \\
\hline register & $\begin{array}{l}-0.034 \\
(0.532)\end{array}$ & $\begin{array}{l}-0.034 \\
(0.544)\end{array}$ & $\begin{array}{l}-0.033 \\
(0.558)\end{array}$ & $\begin{array}{c}0.098 \\
(0.156)\end{array}$ & $\begin{array}{c}0.086 \\
(0.210)\end{array}$ \\
\hline ind & control & control & control & control & control \\
\hline year & control & control & control & control & control \\
\hline $\mathrm{N}$ & 11558 & 10848 & 10848 & 5652 & 5652 \\
\hline adj. R-sq & 0.5322 & 0.5315 & 0.5396 & 0.4749 & 0.4753 \\
\hline
\end{tabular}

Note: The numbers in parentheses are $\mathrm{P}$ values, ${ }^{* * *}$ indicates a significance level of $0.01,{ }^{* *}$ indicates a significance level of 0.05 , and ${ }^{*}$ indicates a significance level of 0.1 .

company's competitive position is -0.759 and the $\mathrm{P}$ value is 0.196 . At this time, the negative impact of the company's competitive position on audit fees is no longer significant; in the low-growth group. The regression coefficient of the competitive position of the company is -0.327 and the $\mathrm{P}$ value is 0.029 . At this time, the competitive position of the company still has a negative impact on audit fees at a significance level of $5 \%$. Based on the above results, it can be determined that the corporate growth variable has a weakening effect on the relationship between enterprises' competitive position and audit fees. High growth can effectively reduce the negative impact of competitive status on audit fees, so $\mathrm{H} 3$ is established. 
Table 5. Multiple regression analysis results 2.

\begin{tabular}{|c|c|c|c|c|c|c|}
\hline & $\begin{array}{c}\text { Full } \\
\text { sample }\end{array}$ & $\begin{array}{l}\text { High } \\
\text { growth }\end{array}$ & $\begin{array}{l}\text { Low } \\
\text { growth }\end{array}$ & $\begin{array}{c}\text { Full } \\
\text { sample }\end{array}$ & $\begin{array}{l}\text { High } \\
\text { growth }\end{array}$ & $\begin{array}{c}\text { Low } \\
\text { growth }\end{array}$ \\
\hline $\begin{array}{l}\text { Instrument } \\
\text { variable }\end{array}$ & & & & \multicolumn{3}{|c|}{$\begin{array}{c}\text { Variables in executive shareholding } \\
\text { and corporate competitive status } \\
\text { lagged by one period }\end{array}$} \\
\hline PCM & $\begin{array}{c}-0.188^{* * *} \\
(0.000)\end{array}$ & $\begin{array}{c}-0.024^{* * *} \\
(0.002)\end{array}$ & $\begin{array}{c}-0.020^{* *} \\
(0.019)\end{array}$ & $\begin{array}{c}-0.608^{* * *} \\
(0.009)\end{array}$ & $\begin{array}{l}-0.759 \\
(0.196)\end{array}$ & $\begin{array}{c}-0.327^{* *} \\
(0.029)\end{array}$ \\
\hline size & $\begin{array}{c}0.339^{\star * *} \\
(0.000)\end{array}$ & $\begin{array}{c}0.056^{* * *} \\
(0.000)\end{array}$ & $\begin{array}{c}0.057^{\star * *} \\
(0.000)\end{array}$ & $\begin{array}{c}0.368^{* * *} \\
(0.000)\end{array}$ & $\begin{array}{c}0.393^{* * *} \\
(0.000)\end{array}$ & $\begin{array}{c}0.262^{* * *} \\
(0.000)\end{array}$ \\
\hline roa & $\begin{array}{c}0.493^{* * *} \\
(0.000)\end{array}$ & $\begin{array}{c}1.376^{* * *} \\
(0.000)\end{array}$ & $\begin{array}{c}0.856^{\star * *} \\
(0.000)\end{array}$ & $\begin{array}{c}0.844^{\star * *} \\
(0.009)\end{array}$ & $\begin{array}{c}1.119 \\
(0.180)\end{array}$ & $\begin{array}{c}0.065 \\
(0.756)\end{array}$ \\
\hline lev & $\begin{array}{c}0.120^{\star * *} \\
(0.004)\end{array}$ & $\begin{array}{c}-0.079^{\star * *} \\
(0.002)\end{array}$ & $\begin{array}{c}-0.063^{\star * *} \\
(0.005)\end{array}$ & $\begin{array}{l}0.073^{* *} \\
(0.050)\end{array}$ & $\begin{array}{c}-0.0343 \\
(0.681)\end{array}$ & $\begin{array}{c}0.016 \\
(0.739)\end{array}$ \\
\hline inv & $\begin{array}{c}0.086 \\
(0.184)\end{array}$ & $\begin{array}{c}0.002 \\
(0.977)\end{array}$ & $\begin{array}{c}0.013 \\
(0.714)\end{array}$ & $\begin{array}{l}0.118^{*} \\
(0.057)\end{array}$ & $\begin{array}{l}0.327^{* *} \\
(0.014)\end{array}$ & $\begin{array}{c}0.052 \\
(0.501)\end{array}$ \\
\hline rec & $\begin{array}{c}0.109 \\
(0.211)\end{array}$ & $\begin{array}{c}0.040 \\
(0.363)\end{array}$ & $\begin{array}{c}0.248^{* * *} \\
(0.000)\end{array}$ & $\begin{array}{l}0.198^{\star *} \\
(0.025)\end{array}$ & $\begin{array}{l}0.351^{\star *} \\
(0.034)\end{array}$ & $\begin{array}{c}0.084 \\
(0.477)\end{array}$ \\
\hline loss & $\begin{array}{l}0.025^{\star *} \\
(0.017)\end{array}$ & $\begin{array}{l}-0.005 \\
(0.778)\end{array}$ & $\begin{array}{c}-0.026^{\star * *} \\
(0.000)\end{array}$ & $\begin{array}{c}0.009 \\
(0.529)\end{array}$ & $\begin{array}{l}0.133^{\star *} \\
(0.013)\end{array}$ & $\begin{array}{l}-0.021 \\
(0.135)\end{array}$ \\
\hline ownership & $\begin{array}{l}-0.001 \\
(0.984)\end{array}$ & $\begin{array}{l}-0.043 \\
(0.106)\end{array}$ & $\begin{array}{c}0.017 \\
(0.174)\end{array}$ & $\begin{array}{c}0.031 \\
(0.350)\end{array}$ & $\begin{array}{l}0.203^{\star *} \\
(0.015)\end{array}$ & $\begin{array}{c}0.020 \\
(0.609)\end{array}$ \\
\hline change & $\begin{array}{l}-0.003 \\
(0.499)\end{array}$ & $\begin{array}{c}-0.0004 \\
(0.871)\end{array}$ & $\begin{array}{l}-.0020 \\
(0.319)\end{array}$ & $\begin{array}{c}0.002 \\
(0.745)\end{array}$ & $\begin{array}{l}-0.007 \\
(0.557)\end{array}$ & $\begin{array}{l}0.0001 \\
(0.989)\end{array}$ \\
\hline big4 & $\begin{array}{c}0.177^{\star * *} \\
(0.001)\end{array}$ & $\begin{array}{l}-0.042 \\
(0.100)\end{array}$ & $\begin{array}{c}0.007 \\
(0.646)\end{array}$ & $\begin{array}{c}0.215^{\star * *} \\
(0.000)\end{array}$ & $\begin{array}{c}0.310^{\star * *} \\
(0.000)\end{array}$ & $\begin{array}{c}0.165^{\star * *} \\
(0.000)\end{array}$ \\
\hline register & $\begin{array}{l}-0.034 \\
(0.532)\end{array}$ & $\begin{array}{c}-0.061^{*} \\
(0.053)\end{array}$ & $\begin{array}{c}0.010 \\
(0.807)\end{array}$ & $\begin{array}{c}0.098 \\
(0.156)\end{array}$ & $\begin{array}{l}-0.068 \\
(0.754)\end{array}$ & $\begin{array}{c}0.066 \\
(0.361)\end{array}$ \\
\hline ind & control & control & control & control & control & control \\
\hline year & control & control & control & control & control & control \\
\hline $\mathrm{N}$ & 11558 & 4334 & 7224 & 5652 & 2042 & 3610 \\
\hline adj. R-sq & 0.5322 & 0.1906 & 0.2545 & 0.4749 & 0.4138 & 0.3284 \\
\hline
\end{tabular}

Note: The numbers in parentheses are $\mathrm{P}$ values, ${ }^{* * *}$ indicates a significance level of $0.01,{ }^{* *}$ indicates a significance level of 0.05 , and ${ }^{*}$ indicates a significance level of 0.1 .

\subsection{Robustness Test}

This paper tests the robustness of the research results by using different variable measurement methods. According to the research of Xing and Chen (2013), the Lerner Index ranking (R-PCM) is used to measure the competitive position of enterprises, that is, the Lerner Index of each company in that year is sorted from small to large, and in this order, the companies in the industry are equally divided into 10 groups, assign the listed companies (R-PCM) in each group to 1 to 10. The higher the R-PCM value, the higher the company's competitive position in the market and the higher its pricing power. In this way, it is brought into the original regression, assuming that one, two, and three are also true. 
Use other corporate growth variables to replace, such as the original sustainable growth rate and Tobin $\mathrm{Q}$ value; or use the principal component analysis method to select multiple growth indicators to obtain comprehensive indicators of growth and bring them into the original regression for robustness testing. This method is used to bring into the original regression, assuming that two or three are still valid. Due to space limitations, specific results are no longer shown.

\section{Research Results, Deficiencies and Prospects}

From the perspective of the theory of audit demand insurance and principal-agent theory, this paper studies the relationship between enterprises' competitive position, corporate growth and audit fees. The results show that the higher the competitive position of the company, the lower the business risk, the lower the corresponding audit risk, and the lower the audit fee required by the auditor. Therefore, the competitive position of the company has a negative impact on audit fees; the risks faced by high-growth companies are relatively high, which leads to higher audit risks for auditors. In order to avoid risks, the required audit fees are higher, so the growth of the company has a positive impact on audit fees; in the end, high-growth companies will change the competitive position of the industry in some ways to change their competitive position. Therefore, the growth of the company has weakened the relationship between the competitive position of the company and the audit fees; that is, in the high-growth sample companies, the significant negative impact of competitive position on audit costs is weakened.

According to the research results of this paper and the actual situation of Chinese listed companies, the following suggestions are made. Firstly, listed companies must be required to continuously improve the company's internal control and risk management system, increase their core competitiveness, and improve their own competitive position. Only starting from the audited entity can inject momentum into the development and growth of Chinese enterprises, optimize the structure of the capital market, and lay the foundation for China's rapid economic growth; at the same time, the auditor can effectively monitor the internal financial operation of the enterprise through the audit work and safeguard the interests of investors. Therefore, this article recommends that accounting firms and auditors continue to improve their own practice capabilities and audit quality, adhere to risk-oriented audit awareness, and pay full attention to the factors that may affect the overall audit risk of the audited unit. Finally, this paper gives a new perspective for auditors to collect audit fees from the perspective of corporate competitive position and growth. The study has certain significance for the regulation of accounting firm audit fees.

Due to objective reasons, this paper has some shortcomings. First, this article uses only 6 years of financial data of Chinese A-share listed companies for empirical analysis. Due to the lack of data, this may have a negative impact on the robustness of the results. Future research will increase the number of sample companies for further analysis to improve this situation; at the same time, this 
article does not consider some macro factors related to audit policy changes. Although some endogenous problems are solved through instrumental variables, there are still shortcomings. Finally, the data and literature in this article mainly come from the Chinese market; this result may not apply in capital markets and audit markets in other parts of the world. In the future, more detailed research can be conducted by refining all aspects of corporate growth and adding adjustments or intermediary variables such as corporate risk.

\section{Conflicts of Interest}

The author declares no conflicts of interest regarding the publication of this paper.

\section{References}

Alimov, A. (2014). Product Market Competition and the Value of Corporate Cash: Evidence from Trade Liberalization. Journal of Corporate Finance, 25, 122-139. https://doi.org/10.1016/j.jcorpfin.2013.11.011

Ariningrum, I., \& Diyanty, V. (2017). The Impact of Political Connections and the Effectiveness of Board of Commissioner and Audit Committees on Audit Fees. Australasian Accounting Business and Finance Journal, 11, 53-70. https://doi.org/10.14453/aabfj.v11i4.5

Bartram, S., Brown, M. G., \& Stulz, R. M. (2012). Why Are U.S. Stocks More Volatile? Journal of Finance, 67, 1329-1370. https://doi.org/10.1111/j.1540-6261.2012.01749.x

Bushman, R. M., Hendricks, B. E., \& Williams, C. D. (2016). Bank Competition: Measurement, Decision-Making, and Risk-Taking. Journal of Accounting Research, 54, 777-826. https://doi.org/10.1111/1475-679X.12117

Cao, H. M., \& Chang, Y. (2015). Analysis on the Impact of Corporate Financial Credit Evaluation on Growth. Economic Issues, No. 10, 113-117.

Chen, J., \& Xu, Y. D. (2011). Product Market Competition, Competitive Situation and Earnings Management of Listed Companies. Finance and Economics Research, No. 4, 58-61.

Choi, J. H., Kim, J. B., Liu, X. et al. (2008). Audit Pricing, Legal Liability Regimes, and Big 4 Premiums: Theory and Cross-Country Evidence. Contemporary Accounting Research, 25, 55-99. https://doi.org/10.1506/car.25.1.2

Cullen, G., Gasbarro, D., Monroe, G. et al. (2018). Bank Audit Fees and Asset Securitization Risks. Auditing: A Journal of Practice \& Theory, 29, 57-82.

Hang, \& Shin, I. L. (2018). The Relationship between Firm Market Power and Audit Fee Decisions. The Journal of International Trade \& Commerce, 14, 88-89.

https://doi.org/10.16980/jitc.14.3.201806.89

He, W. F., \& Liu, W. (2015). Enterprise Manager's Ability and Audit Fees. Accounting Research, No. 1, 82-89+97.

Huang, Y., Jennings, R., \& Yu, Y. (2017). Product Market Competition and Managerial Disclosure of Earnings Forecasts: Evidence from Import Tariff Rate Reductions. Social Science Electronic Publishing, 92, 185-207. https://doi.org/10.2308/accr-51558

Irvine, P., \& Pontiff, J. (2009). Idiosyncratic Return Volatility, Cash Flows, and Product Market Competition. Review of Financial Studies, 22, 1149-1177.

https://doi.org/10.1093/rfs/hhn039 
Leventis, S., \& Dimitropoulos, P. E. (2010). Audit Pricing, Quality of Earnings and Board Independence: The Case of the Athens Stock Exchange. Advances in Accounting, 26, 325-332. https://doi.org/10.1016/j.adiac.2010.08.002

Li, J. T., Wang, D. M., \& Yang, Y. C. (2012). Research on the Correlation between Auditor's Personal Characteristics and Audit Expense Rate: Empirical Data from Chinese Listed Companies in 2009. Chinese Certified Public Accountant, No. 3, 58-64 + 3.

Li, X. (2015). Realistic Consideration of Enterprise Growth Level, Audit Opinions and Risk Premium Based on Industry Differences. Journal of Finance and Accounting Monthly, No. 14, 80-84.

Li, Y. D., Zhang, D., \& Liu, W. W. (2014). Major Internal Control Defects, Property Rights and Audit Pricing. Audit Research, No. 2, 45-52.

Lin, C., Cao, G. H., Qiu, B. H., \& Bi, J. Y. (2011). CEO Control, Growth and Audit Pricing. Contemporary Finance and Economics, No. 4, 110-119.

Liu, Q. L., Li, Y., Zhao, C., Liao, Y. G., \& Chen, H. W. (2014). Negative Media Reports, Litigation Risks and Audit Costs. Accounting Research, No. 6, 81-88 + 97.

Liu, X. X., Li, M. H., \& Sun, L. (2017). Negative Media Reports, Audit Pricing and Audit Delays. Accounting Research, No. 4, 88-94 + 96.

Liu, Y., \& Luo, Z. L. (2018). Customer Relationship Investment, Product Market Competition and Auditor Pricing Decision. Journal of Shanxi University of Finance and Economics, 40, 110-124.

Liu, Y., \& Min, J. (2018). Quality of Internal Control, Enterprise Growth and Credit Risk. Finance and Accounting Newsletter, No. 24, 106-110 + 129.

Lu, C. J., Jin, C., \& Chen, Y. (2006). An Empirical Study on the Impact of Financial Leverage on Corporate Growth. Research on Financial and Economic Issues, No. 2, 80-85.

Ma, H., \& Wang, Y. Y. (2015). Financing Constraints, Government Subsidies and Corporate Growth-An Empirical Study Based on China's Strategic Emerging Industries. China Management Science, No. s1, 630-636.

Ma, L. L., Shen, J. Q., \& Tian, X. Y. (2018). Research on the Impact of the Incentive Mechanism of Executives of Listed Companies on Audit Costs. Journal of Wuhan University of Technology (Information and Management Engineering Edition), 40, 455-459 + 470 .

Ni, X. Y., Dai, D. M., \& Zhang, D. X. (2017). Equity Incentives and Audit Fees: Empirical Evidence from China. Audit Research, No. 1, 69-77.

Vafeas, N., \& Waegelein, J. F. (2007). The Association between Audit Committees, Compensation Incentives, and Corporate Audit Fees. Review of Quantitative Finance and Accounting, 28, 241-255. https://doi.org/10.1007/s11156-006-0012-9

Wang, X. Y., Wang, P., \& Zhang, J. P. (2014). Customer Concentration and Audit Costs: Customer Risk or Supply Chain Integration. Audit Research, No. 6, 72-82.

Wang, Y., \& Chui, A. C. W. (2010). Product Market Competition and Audit Fees. Social Science Electronic Publishing, 34. https://doi.org/10.2139/ssrn.1697685

Wei, L. X., Huang, G. L., \& Zhang, M. (2017). Research on the Relationship between Managers' Risk Preference and Accounting Information Transparency: Based on the Perspective of Enterprise Growth. Finance and Accounting News, No. 25, 25-29.

Wu, H. J., Han, J. Q., \& Li, W. L. (2016). Growth, Product Market Competition and Cash Holding: Based on Empirical Evidence from Chinese Listed Companies. Journal of Guizhou University of Finance and Economics, No. 2, 51-61.

Wu, H. J., Tan, W. R., \& Yang, X. Q. (2015). Product Market Competition, Growth and 
Stock Characteristic Fluctuations: Based on Empirical Evidence from Chinese Listed Companies. Journal of Zhongnan University of Economics and Law, No. 6, 127-137+ 160.

Wu, H. J., Yang, X. Q., \& Wei, H. (2012). Product Market Competition and Company Stock Idiosyncratic Risks: Based on Empirical Evidence of Listed Companies in China. Economic Research, 47, 101-115.

Xiang, Z. H., \& Yang, X. L. (2013). Enterprise Growth, Signal Transmission, Audit Fees and Auditor Selection. Finance and Accounting Newsletter, No. 18, 21-23.

Xing, L. Q., \& Chen, H. W. (2013). Product Market Competition, Competitive Position and Audit Fees: Based on Dual Considerations of Agency Costs and Operating Risks. Audit Research, No. 3, 50-58.

Xing, L. Q., \& Chen, H. W. (2013). Product Market Competition, Competitive Position, and Audit Fees: Based on Dual Considerations of Agency Costs and Operating Risks. Audit Research, No. 3, 50-58.

Xu, Y. X., \& Wang, C. (2012). Risk-Oriented Auditing, Internal Control and Auditor Behavior: Based on Empirical Tests of Listed Companies in China. Economic Review, No. 5, 123-133.

Xu, Y., \& Feng, J. K. (2016). Empirical Research on Executive Shareholding, Audit Pricing and Equity Concentration. Henan Social Sciences, 24, 74-82 + 123.

Yang, R., Yu, Y., Liu, M. et al. (2017). Corporate Risk Disclosure and Audit Fee: A Text Mining Approach. Social Science Electronic Publishing, No. 4, 1-12.

Zhai, S. B., Xu, H. R., Liu, Y. D., \& Tang, W. (2017). Equity Pledge of Controlling Shareholders and Auditor's Risk Response. Management World, No. 10, 51-65.

Zhang, J., \& Huang, Z. Z. (2014). Executive Compensation, Opportunistic Earnings Management and Audit Costs: Based on the Heterogeneity of Earnings Management. Nankai Management Review, No. 3, 74-83 + 93.

Zhang, R., \& Tian, G. L. (2016). Accounting Firm's Industry Expertise, Industry Homogeneity and Auditing Costs: Based on Local Level Investigations. Journal of Shanxi University of Finance and Economics, 38, 101-113.

Zhang, T. S., \& Huang, J. (2013). Research on Audit Fee Risk Premium in Financial Crisis. Accounting Research, No. 5, 81-86 + 96 .

Zhu, C. Y., Wu, L. N., \& Tian, L. H. (2017). The Impact of Agency Costs and Flexible Information Disclosure on Audit Fees. Accounting Research, No. 7, 89-95 + 97. 